\title{
Radish Productivity Under Inclusion \\ of Plant Inedible Biomass in Mass Exchange Processes of a Biological-Technical Life Support System
}

\author{
Sofya A. Ushakova*, \\ Vladimir V. Velichko, Alex A. Tikhomirov, \\ Valentin N. Shikhov and Sergey V. Trifonov \\ Institute of Biophysics SB RAS \\ 50/50 Akademgorodok, Krasnoyarsk, 660036, Russia
}

Received 21.08.2014, received in revised form 25.08.2014, accepted 14.01.2015

Use of the soil-like substrate (SLS) as a root-inhabited substrate is one of the most perspective ways of plants cultivation in biological-technical life support systems (BTLSS). Inclusion of plant inedible biomass seems to be necessary for closure increase of mass exchange processes of a long-functioning BTLSS. The work presents estimation data of three ways of processing wheat and radish inedible biomass introduced into the SLS: a 'biological' method, a physical-technical way and a combined one. Radish (Raphanus sativus L.) "Mokhovsky" variety was a test culture. The 'biological' method represented the SLS used as a bioreactor in which dry wheat and radish inedible biomass was introduced. The physical-technical method consisted of 'wet' oxidation of wheat and radish inedible biomass by hydrogen peroxide in alternating current with further introduction of the solution obtained into the solution for plants irrigation. The combined method included physical-chemical mineralization of wheat straw and radish inedible biomass introduced directly into the SLS. The combined method consisted of the physical-chemical oxidation of wheat straw and the 'biological' processing of radish inedible biomass appeared to be the most optimal way from all methods under study.

Keywords: biological-technical life support systems, soil-like substrate, utilization of plant wastes, production characteristics of radish plants.

\footnotetext{
(C) Siberian Federal University. All rights reserved

* Corresponding author E-mail address: sofya-ushakova@yandex.ru
} 


\title{
Продуктивность редиса при включении несъедобной раститель- ной биомассы в массообменные процессы биолого-технических систем жизнеобеспечения
}

\author{
С.А. Ушакова, В.В. Величко, \\ А.А. Тихомиров, В.Н. Шихов, С.В. Трифонов \\ Институт биофизики СО РАН \\ Россия, 660036, Красноярск, Академгородок, 50/50
}

Использование почвоподобного субстрата (ППС) в качестве корнеобитаемого субстрата является одним из перспективных способов культивирования растений в биолого-технических системах жизнеобеспечения (БТСЖО). Возможным способом увеличения степени замкнутости массообменных процессов в БТСЖО длительного срока функиионирования служст вовлечение в массообменные процессы несъедобной растительной биомассы. В статье приводятся результаты оценки трех способов минерализации несъедобной биомассы пшениць и редиса: «биологический», физико-химический и комбинированный. «Биологический» способ осуществляли путем внесения сухой несъедобной биомассы пшеницы и редиса в ППС, который служил корнеобитаемой средой и биореактором для разложения растительных отходов. Физико-химический способ основан на методе «мокрого» сжигания несъедобной биомассы пшенищы и редиса перекисью водорода в переменном электромагнитном поле с последующим внесением полученного раствора в поливной раствор. Комбинированный способ включал в себя внесение физико-химически минерализованной пшеничной соломы в поливной раствор, а несъедобной биомассы редиса непосредственно в ППС. Состояние растений редиса оиенивали по состоянию фотосинтетического аппарата, по показателям $\mathrm{CO}_{2}$ газообмена комплекса «иеноз редиса - ППС», по продуктивности и другим физиологическим характеристикам. Из исследованных способов минерализации оптимальным оказалось комбинирование физикохимической минерализации соломы пиениць $и$ «биологического» метода минерализации несъедобной биомассы редиса.

Ключевые слова: биолого-технические системы жизнеобеспечения человека, почвоподобный субстрат, утилизация растительных отходов, продукиионная деятельность растений редиса.

\section{Введение}

По оценке специалистов, биологотехническими системами жизнеобеспечения (БТСЖО) длительного срока функционирования будут системы гибридного типа, основанные на биологических и физико-химических способах утилизации отходов жизнедеятель- ности человека (Gitelson et al., 2003; Tikhomirov et al., 2003, 2007; Bamsey et al., 2009). Использование почвоподобного субстрата (ППС) в БТСЖО является одним из перспективных биологических способов вовлечения во внутрисистемный круговорот несъедобной растительной биомассы (Manukovsky et al., 1997; 
Liu et al., 2008; Cheng et al., 2013; Hu et al., 2013; Tikhomirov et al., 2011). В ранее проведенных исследованиях было показано, что выращивание растений на ППС не влияет отрицательно на процессы роста и развития растений. Урожаи растений, выращенных на ППС, прошедшем стадию глубокой минерализации (далее свежеприготовленный), значимо не отличались от урожая этих же растений, полученных при выращивании методом гидропоники на керамзите с использованием стандартной минеральной среды Кнопа (Ушакова и др., 2010).

Помимо «биологического» метода утилизации растительных отходов в Институте биофизики СО РАН был разработан физикохимический способ минерализации растительных отходов и экзометаболитов человека, основанный на окислении органических отходов перекисью водорода в переменном электромагнитном поле, который позволяет включить в массообменные процессы БТСЖО плотные и жидкие выделения человека (Kudenko et al., 1997; Kudenko et al., 2000).

В БТСЖО гибридного типа, разрабатываемой в Институте биофизики СО РАН, ППС служит субстратом для выращивания овощных культур, а метод гидропоники на керамзите используется для выращивания пшеницы. Минерализованные экзометаболиты человека служат основой для приготовления питательных растворов для полива пшеницы, обеспечивая ценозы пшеницы необходимым количеством питательных веществ. Вынос из ППС минеральных элементов со съедобной биомассой овощных растений компенсируется внесением в субстрат несъедобной биомассы пшеницы. Параллельно в ППС вносится несъедобная биомасса выращенных овощей (Tikhomirov et al., 2011). Однако способ внесения растительных отходов пока недостаточно разработан. Поэтому цель настоящей рабо- ты - исследование влияния способа внесения несъедобной биомассы пшеницы и редиса в почвоподобный субстрат на продукционную деятельность тестовой культуры - редиса.

\section{Материалы и методы}

Объектом исследования был выбран редис (Raphanus sativus L.) сорта Моховский, который является одной из основных тесткультур, используемых для изучения влияния различных факторов среды на продукционную деятельность растений в БТСЖО. В ходе проведения экспериментов растения редиса выращивали на ППС при круглосуточном освещении при интенсивности фотосинтетически активной радиации (ФАР) $690 \mu$ моль ${ }^{-2}{ }^{-2} \mathrm{c}^{-1}$ на уровне верхних листьев (Tikhomirov et al., 2003; Ушакова и др., 2010). Температура воздуха была $(24 \pm 1){ }^{\circ} \mathrm{C}, \mathrm{pH}$ несменяемых поливных растворов поддерживали в пределах 7 с помощью коррекции лимонной кислотой (Manukovsky et al., 1997; Tikhomirov et al., 2011). Площадь посева 0,128 м² при плотности посева 180 растений на $1 \mathrm{~m}^{2}$. Длительность вегетационного периода растений редиса составляла 28 сут.

Было проведено два цикла выращивания растений редиса на ППС. Первый цикл - это выращивание редиса на свежеприготовленном ППС. В контрольном варианте первого цикла в субстрат ничего не вносили, а в опытном варианте в субстрат была внесена солома пшеницы, которую равномерно перемешивали с ППС. При внесении сухой соломы в свежеприготовленный ППС перед выращиванием редиса исходили из того, что внесенное в ППС с соломой количество азота должно быть равно количеству азота в предполагаемом урожае корнеплодов редиса. Для расчетов были использованы полученные ранее данные по урожайности редиса и минеральному составу корнеплодов редиса и соломы 
пшеницы, выращенных на нейтральном субстрате (Gitelson et al., 2003). С учетом содержания азота в корнеплодах редиса 1,7 \% при

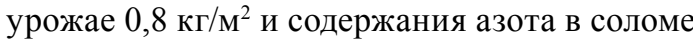

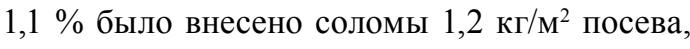
содержащей 13,2 г азота.

Для изучения влияния способа утилизации несъедобной растительной биомассы редиса и пшеницы на рост растений редиса ППС контрольного варианта 1-го цикла эксперимента (после уборки растений) был использован для следующей вегетации растений редиса (второй цикл). Исследовано два способа минерализации растительных отходов: биологический и физико-химический. Биологический метод - в качестве биореактора был взят ППС. Физико-химический «мокрое» сжигание растительных отходов перекисью водорода в переменном электромагнитном поле (Kudenko et al., 1997). Во вторм цикле было четыре варианта эксперимента - один контрольный и три опытных, отличающихся способом внесения растительных отходов в корнеобитаемую среду для выращивания растений. Варианты эксперимента были следующими: вариант 1 (контроль) - в ППС и в ирригационный раствор ничего не вносили, реакцию растений остальных вариантов сравнивали, прежде всего, с этим вариантом; вариант А - в ППС была внесена измельченная несъедобная биомасса выращенного редиса и солома пшеницы, содержание азота в которой было равно содержанию азота в убранных корнеплодах контрольного варианта первого цикла (биологический метод утилизации); вариант Б - в ППС была внесена измельченная несъедобная биомасса выращенного редиса, а в ирригационный раствор - жидкие продукты минерализации физико-химическим методом соломы пшеницы (комбинированное использование методов); вариант В - в ирригационный раствор были внесены жидкие продукты минерализации физико-химическим методом несъедобной биомассы выращенного редиса и соломы пшеницы (физико-химический метод). В табл. 1 представлены все варианты 2-го цикла с количественными характеристиками вносимых в ППС листьев редиса и соломы пшеницы. Минерализованные растворы листьев редиса и соломы пшеницы вносили в ирригационные растворы в течение вегетационного периода ежедневно равными порциями.

В табл. 2 приведены общее и доступное для корневого питания растений содержание минеральных элементов в ППС обоих циклов, минеральный состав используемых во втором цикле эксперимента растворов и биомасс растений.

Состояние растений редиса оценивали по состоянию фотосинтетического аппарата, по показателям $\mathrm{CO}_{2}$ газообмена, по продук-

Таблица 1. Описание вариантов во 2-м цикле экспериментов

\begin{tabular}{|c|c|c|c|c|c|}
\hline \multirow{2}{*}{ Варианты } & \multicolumn{3}{|c|}{ Сухая масса, г } & \multicolumn{2}{c|}{ Минерализованный раствор, мл } \\
\cline { 2 - 6 } & ППС & $\begin{array}{c}\text { Солома } \\
\text { пшеницы }\end{array}$ & Листья редиса & $\begin{array}{c}\text { Солома } \\
\text { пшеницы }\end{array}$ & Листья редиса \\
\hline Контроль & 2800 & - & - & - & - \\
А & 2800 & 59,1 & 43,4 & - & - \\
Б & 2800 & - & 43,4 & 1592 & 804 \\
В & 2800 & - & - & 1592 & - \\
\hline
\end{tabular}


Таблица 2. Содержание минеральных элементов в ППС, в несъедобной биомассе пшеницы и редиса, в жидких продуктах минерализации несъедобной биомассы пшеницы и редиса

\begin{tabular}{|c|c|c|c|c|c|c|}
\hline Образец & $\mathrm{K}$ & $\mathrm{P}$ & $\mathrm{S}$ & $\mathrm{Ca}$ & $\mathrm{Mg}$ & $\mathrm{N}$ \\
\hline $\begin{array}{l}\text { Свежеприготовленный ППС, мг/г сухого } \\
\text { ППС }\end{array}$ & 12,5 & 8,6 & 5,6 & 79,9 & 7,3 & 26,9 \\
\hline $\begin{array}{l}\text { Доступные для растений элементы, мг/Г } \\
\text { сухого ППС }\end{array}$ & 10,5 & 3,4 & 2,1 & 49,9 & 4,6 & 3,5 \\
\hline $\begin{array}{l}\text { ППС в начале 2-го цикла, мг/г сухого } \\
\text { ППС }\end{array}$ & 13,1 & 8,8 & 5,1 & 86,5 & 8,4 & 22,1 \\
\hline $\begin{array}{l}\text { Доступные для растений элементы, мг/Г } \\
\text { сухого ППС }\end{array}$ & 9,2 & 2,2 & 1,8 & 60,6 & 5,0 & 2,2 \\
\hline $\begin{array}{l}\text { Измельченная солома для 2-го } \\
\text { цикла, мг/г сухого вещества }\end{array}$ & 17,5 & 2,4 & 1,6 & 7,0 & 1,6 & 11,0 \\
\hline $\begin{array}{l}\text { Измельченные листья редиса, мг/г сухого } \\
\text { вещества }\end{array}$ & 92,5 & 4,4 & 6,6 & 28,0 & 6,5 & 50,9 \\
\hline Минерализованная солома, мг/л & 800,0 & 275,4 & 100,0 & 225,9 & 62,3 & 466,6 \\
\hline Минерализованные листья редиса, мг/л & 1900,0 & 176,0 & 320,0 & 1600,0 & 192,9 & 1851,1 \\
\hline Отстоянная водопроводная вода, мг/л & 0,9 & 2,7 & 2,3 & 22,1 & 3,0 & - \\
\hline
\end{tabular}

тивности и минеральному составу съедобной и несъедобной биомассы.

Состояние фотосинтетического аппарата растений редиса оценивали на основании флуоресцентного анализа с использованием стандартных параметров импульсно-модулированной флуоресценции хлорофилла, полученных при использовании портативного флуориметра PAM 2100 (Walz, Germany): максимальный квантовый выход первичного разделения зарядов в ФС2 (параметр $\left.\mathrm{F}_{\mathrm{v}} / \mathrm{F}_{\mathrm{m}}\right)$, эффективный квантовый выход ФС2 (параметр Yield), скорость электронного транспорта (параметр ETR), фотохимическое тушение флуоресценции хлорофилла в ФС2 (параметр qP), нефотохимическое тушение флуоресценции хлорофилла (параметр qN) (Roháček, 2002; Roháček, Barták, 1999). Измерения флуоресценции проводили на хорошо освещенных зрелых листьях, находящихся в верхней части ценоза, в четырех повторностях для каждого исследуемого варианта.

Показатели $\mathrm{CO}_{2}$ газообмена оценивали на основании измерения концентрации $\mathrm{CO}_{2}$ В герметичной вегетационной камере с помощью газоанализатора LI-820 (LI-COR, CША) через каждые 7 суток в течение вегетационного периода. Видимый фотосинтез оценивали по скорости изменения концентрации $\mathrm{CO}_{2}$ на свету, дыхание - по скорости изменения концентрации $\mathrm{CO}_{2}$ в первые 30 мин после выключения света, гросс-фотосинтез рассчитывали как сумму видимого фотосинтеза и дыхания.

Минеральный состав образцов анализировали методами, описанными в работе (Kalacheva, 2002). Определение подвижных форм элементов, содержащихся в ППС, проводили в водной и солянокислой вытяжках (Минеев, 2001).

Эксперименты проведены в двух повторностях. В каждой повторности было не менее трех биологических повторностей. В таблицах и на графиках представлены данные в виде средних арифметических значений. Достоверность различий между средними определяли по критерию Стьюдента при уровне значимости $\alpha \leq 0,05$. 


\section{Результаты и обсуждение}

Выращивание растений на

свежеприготовленном ППС

Характеристика урожая редиса, выращенного в 1-м цикле экспериментов, приведена в табл. 3. Из сравнения урожаев опытного и контрольного вариантов видно, что внесение соломы в субстрат привело к уменьшению сырой и сухой надземной массы редиса в 2,4 и 2,0 раза соответственно. При этом в листьях опытного варианта доля сухого вещества оказалась несколько выше, чем в контроле, что связано с более низкой оводненностью тканей. Внесение соломы значительно повлияло и на массу корнеплодов, сырая и сухая масса которых уменьшилась более чем в 1,6 раза.

Одной из основных причин снижения урожая растений может быть недостаток доступных для растений элементов минерального питания. Дефицит нутриентов может возникнуть из-за микроорганизмов, способствующих разложению внесенной соломы. Конкуренция между микроорганизмами и растениями возникает из-за низкого уровня минерализации азотосодержащих соединений (Мишустин, 1972; Tarkalson et al., 2009). Другая причина может быть связана с токсичностью для растений продуктов разложения соломы, отличающейся высоким содержанием лигнина (Бохински, 1987). При окислении лигнина могут образовываться биологически активные соединения, оказывающее отрица- тельное воздействие на процессы роста растений (Мануковский, 1990).

Таким образом, внесение сухой соломы в свежеприготовленный ППС при последующем выращивании на нем растений редиса привело к значительному снижению общей продуктивности и уменьшению хозяйственнополезного урожая растений. Поэтому в следующей серии экспериментов была изучена возможность снижения отрицательного влияния внесения несъедобной биомассы растений за счет их предварительной обработки без дополнительного внесения азотных удобрений.

Выращивание растений на ППС

с различными способами

минерализации растительных отходов

Содержание азота в ирригационных pacmвopax. Различные способы минерализации несъедобной растительной биомассы перед ее внесением в корнеобитаемую среду оказали существенное влияние на содержание азота в ирригационном растворе. На рис. 1 и 2 показана динамика содержания нитратного и общего азота в растворе в течение вегетационного периода, начиная с 11-суточного возраста ценоза редиса. Видно, что наибольшее содержание общего и нитратного азота было в ирригационном растворе варианта Б при сравнительно близком его содержании в контроле и в вариантах А и В. Таким образом, растения в варианте Б по сравнению с растениями других вариантов находились в более

Таблица 3. Урожай редиса, выращенного на ППС (контроль) и на ППС с добавлением соломы

\begin{tabular}{|c|c|c|c|c|c|c|}
\hline \multirow{3}{*}{$\begin{array}{c}\text { Часть } \\
\text { растения }\end{array}$} & \multicolumn{3}{|c|}{ Контроль } & \multicolumn{3}{|c|}{ Опыт } \\
\hline & \multicolumn{2}{|c|}{ Биомасса, кг/м² } & \multirow{2}{*}{$\begin{array}{l}\text { \% сухого } \\
\text { вещества }\end{array}$} & \multicolumn{2}{|c|}{ Биомасса, кг/м ${ }^{2}$} & \multirow{2}{*}{$\begin{array}{l}\% \text { сухого } \\
\text { вещества }\end{array}$} \\
\hline & сырая & сухая & & сырая & сухая & \\
\hline Надземная & $2,9 \pm 0,4$ & $0,40 \pm 0,10$ & $14,0 \pm 0,7$ & $1,2 \pm 0,2$ & $0,20 \pm 0,02$ & $17,0 \pm 1,0$ \\
\hline Корнеплоды & $3,1 \pm 0,5$ & $0,25 \pm 0,13$ & $8,0 \pm 0,5$ & $1,9 \pm 0,6$ & $0,15 \pm 0,05$ & $8,0 \pm 0,6$ \\
\hline
\end{tabular}




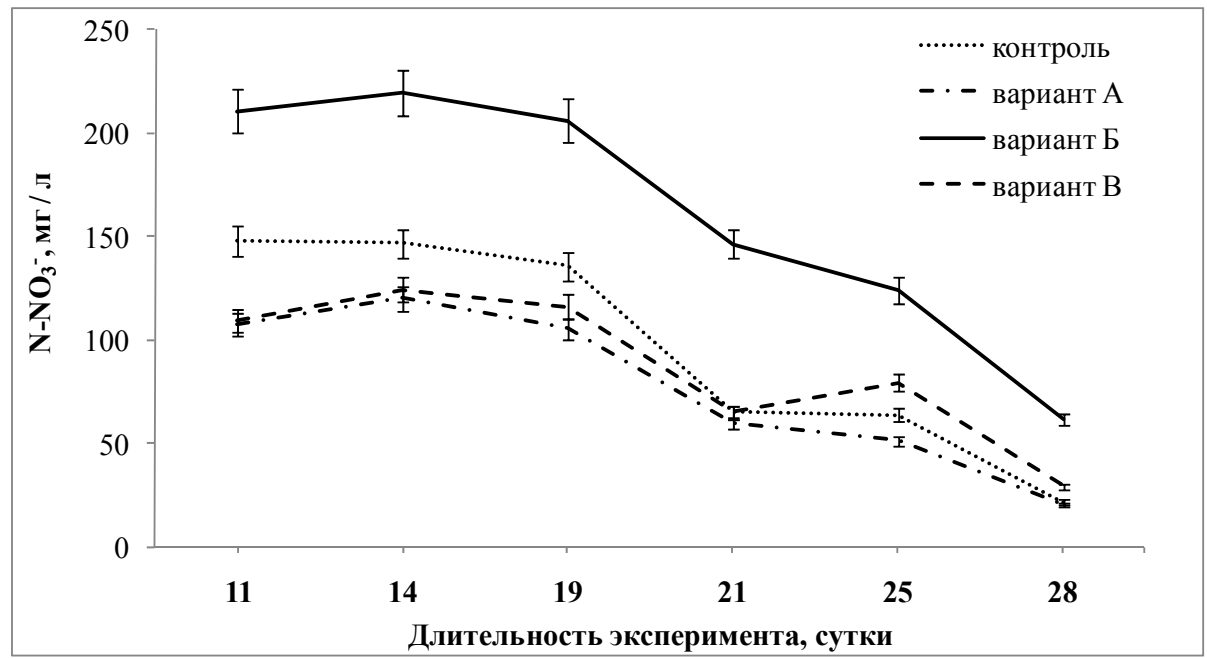

Рис. 1. Содержание нитратных форм азота в ирригационных растворах цикла 2. Контроль - без внесения растительной биомассы в ППС; вариант А - биологический метод минерализации растительной биомассы; вариант Б - комбинированный метод минерализации растительной биомассы; вариант В - физикохимический метод минерализации растительной биомассы

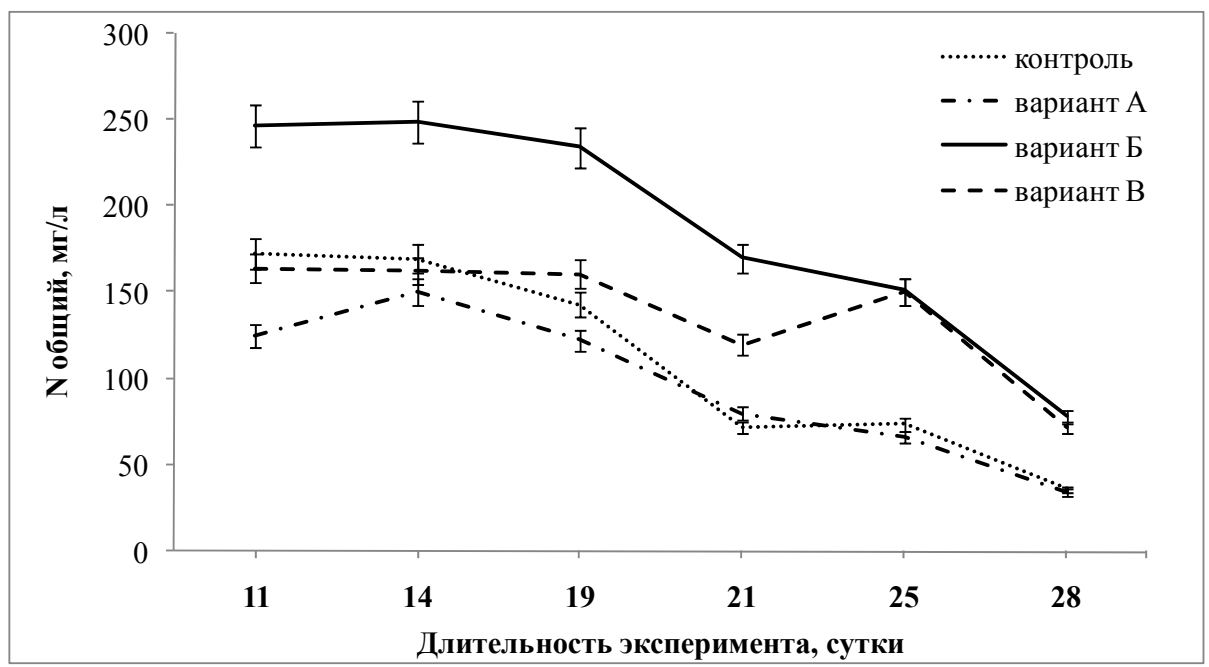

Рис. 2. Содержание общего азота в ирригационных растворах цикла 2. Обозначения вариантов эксперимента как на рис. 1

благоприятных условиях по обеспеченности азотом (рис. 2).

Внесение в ирригационный раствор минерализованной физико-химическим методом несъедобной биомассы пшеницы и редиса привело в варианте В к мало меняющемуся в процессе роста растений содержанию в рас- творе общего азота за счет регулярно вносимых в раствор восстановленных форм азота (рис. 2, 3). В варианте Б, где в ирригационный раствор вносили жидкие продукты минерализации соломы пшеницы, содержание восстановленного азота колебалось в диапазоне 20-30 мг/л (рис. 3). В контроле и в ва- 


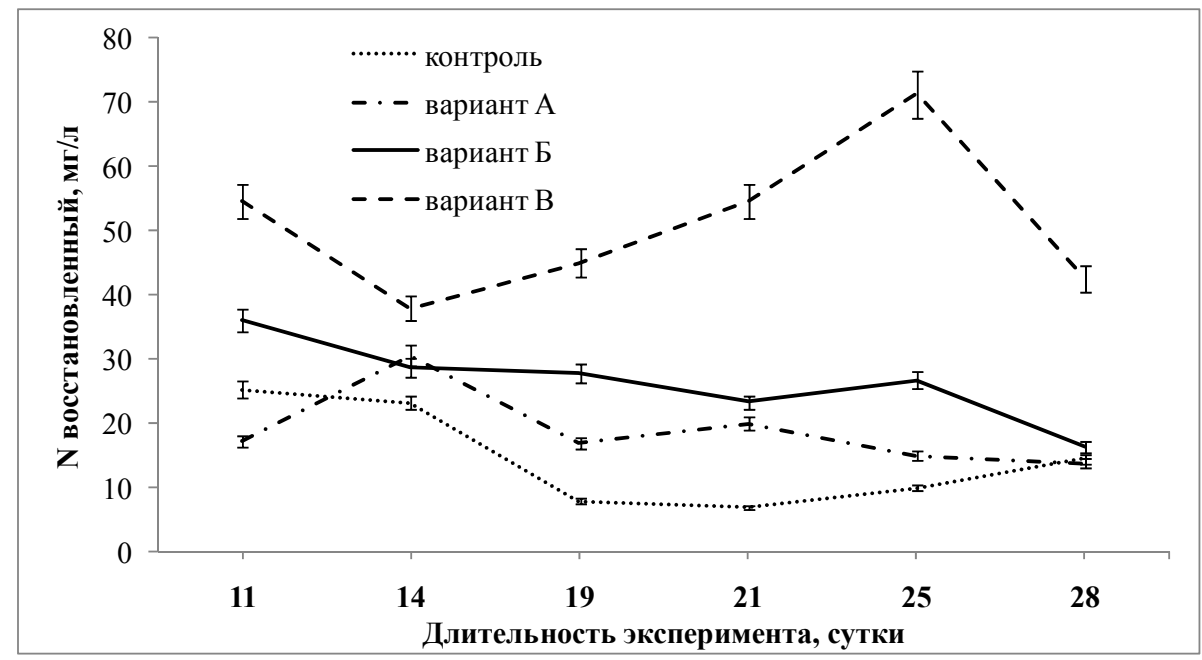

Рис. 3. Содержание восстановленных форм азота в ирригационных растворах цикла 2. Обозначения вариантов эксперимента как на рис. 1

рианте А после 14 суток вегетации растений концентрация восстановленных форм азота в растворе не превышала 20 мг/л (рис. 3).

Состояние фотосинтетического апnарата растений редиса. Значения флуоресцентных параметров растений редиса, выращенных при разных способах внесения растительных отходов в корнеобитаемый субстрат, не имели достоверных отличий в ходе всего вегетационного периода (рис. 4). При этом на всем протяжении роста растений значения максимального квантового выхода ФС2 находились в пределах нормы (выше 0,74 отн. ед.) и, следовательно, не указывали на то, что фотосинтетический аппарат растений был в стрессовом состоянии (van Kooten, 1990).

$\mathrm{CO}_{2}$-газообмен. При отсутствии отличий в функциональном состоянии фотосинтетического аппарата растений показатели $\mathrm{CO}_{2}$ газообмена комплексов «ценоз редиса - ППС» отреагировали на способ внесения в корнеобитаемую среду растительных отходов.

В первые сутки вегетации наибольшая скорость видимого выделения $\mathrm{CO}_{2}$ на свету наблюдалась при внесении в субстрат несъедобной биомассы растений редиса и пшеницы. Довольно значительным выделение $\mathrm{CO}_{2}$ было и в варианте с комбинированным методом внесения растительных отходов, что говорит о том, что именно в этот период идет интенсивное разложение внесенного органического вещества. В контрольном варианте и варианте с использованием полностью минерализованных растительных отходов интенсивности выделения $\mathrm{CO}_{2}$ были близки и связаны в основном с интенсивностью дыхания непосредственно ППС (рис. 5 и 6).

В процессе роста растений происходило увеличение роли фотосинтетических и окислительных процессов во внешнем газообмене комплекса «ценоз редиса - ППС», связанное с жизнедеятельностью растений, и снижение вклада окислительных процессов, протекающих в корнеобитаемом субстрате (рис. 5 и 6).

После 14 сут с начала экспериментов интенсивность дыхания комплексов «ценоз редиса - ППС» между вариантами достоверно не отличалась. Видимо, к этому моменту 

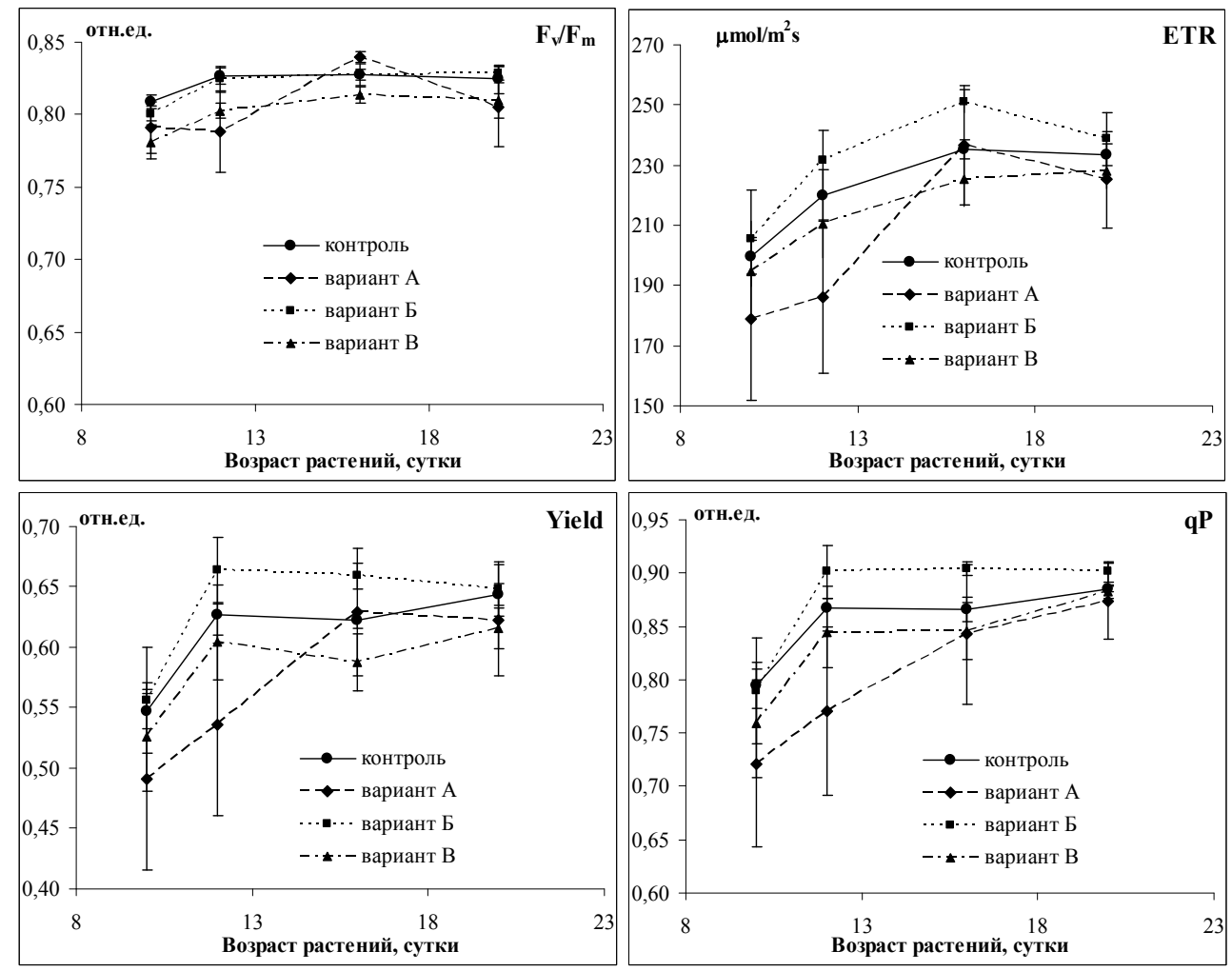

Рис. 4. Флуоресцентные показатели состояния фотосинтетического аппарата растений редиса, выращенных на ППС при разных способах минерализации растительных отходов. $\mathrm{F}_{\mathrm{v}} / \mathrm{F}_{\mathrm{m}}-$ максимальный квантовый выход первичного разделения зарядов в ФС2; Yield - эффективный квантовый выход ФС2; $\mathrm{ETR}$ - скорость электронного транспорта; qP - фотохимическое тушение флуоресценции хлорофилла в ФС2; qN - нефотохимическое тушение флуоресценции хлорофилла. Обозначения вариантов эксперимента как на рис. 1

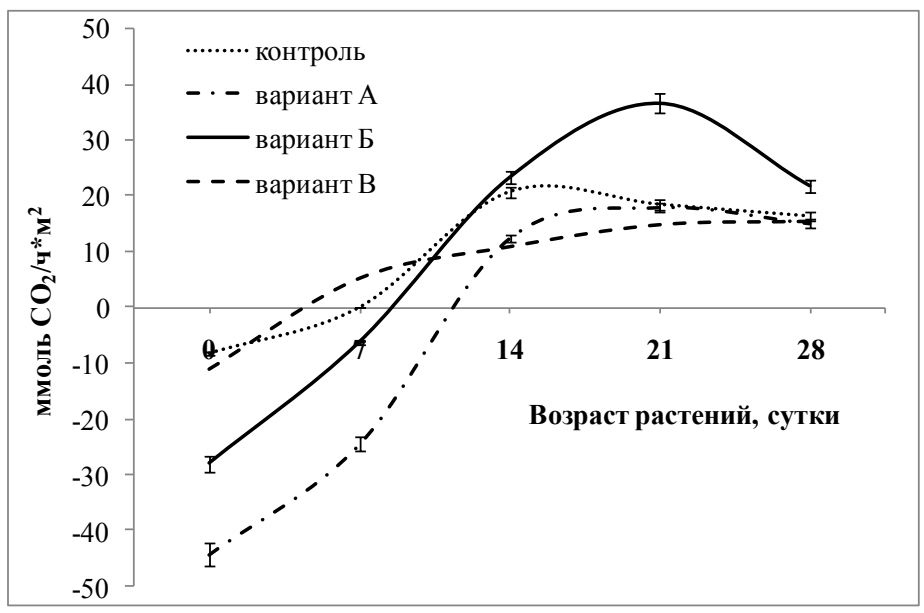

Рис. 5. $\mathrm{CO}_{2}$-газообмен комплекса «ценоз редиса - ППС» на свету в зависимости от способа минерализации растительных отходов перед внесением в ППС. Обозначения вариантов эксперимента как на рис. 1 


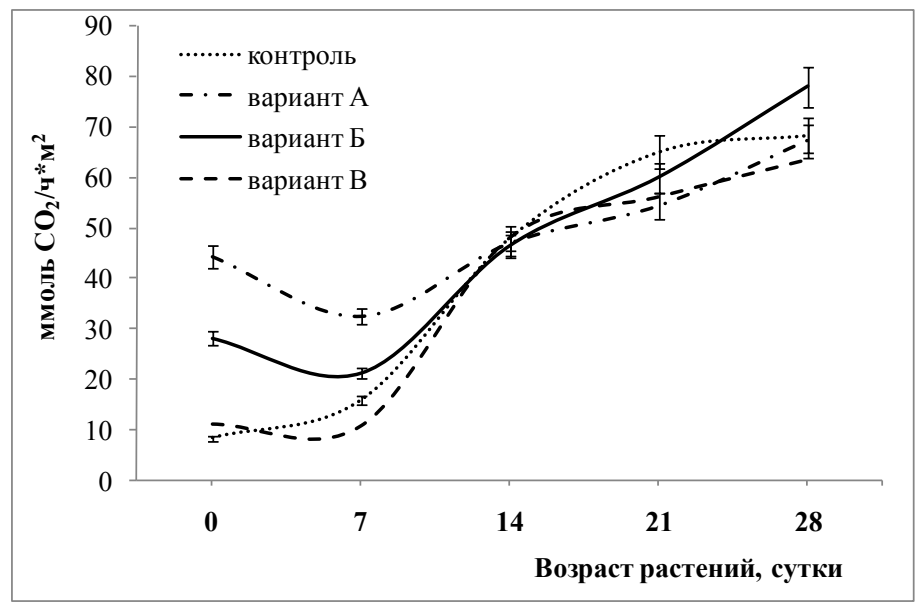

Рис. 6. Дыхание комплекса «ценоз редиса - ППС» на свету в зависимости от способа минерализации растительных отходов перед внесением в ППС. Обозначения вариантов эксперимента как на рис. 1

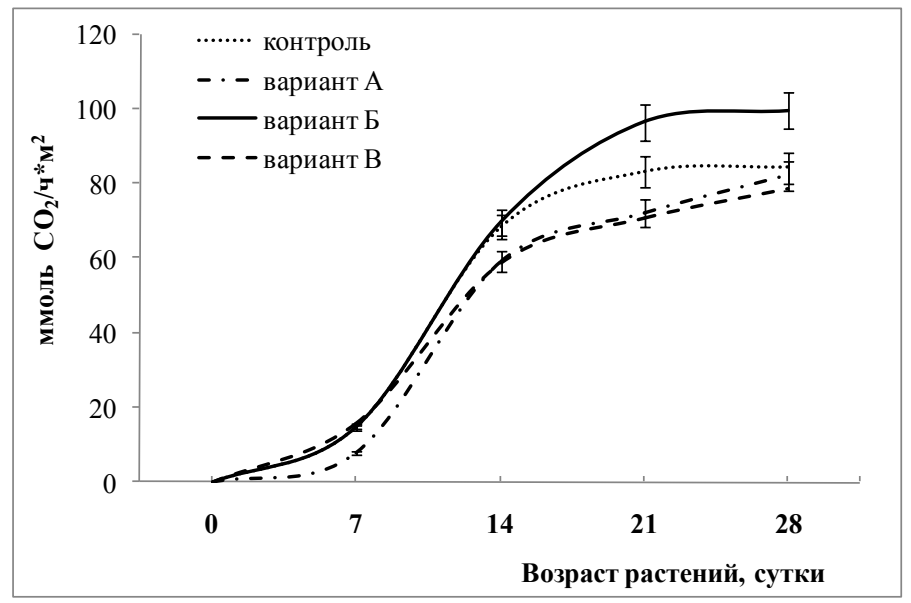

Рис. 7. Гросс-фотосинтез ценоза редиса в зависимости от способа минерализации растительных отходов перед внесением в ППС. Обозначения вариантов эксперимента как на рис. 1

произошло разложение более или менее легко окисляемой внесенной органической массы, а интенсивность окисления оставшегося органического вещества мало отличалась от интенсивности окисления органического вещества самого ППС.

Интенсивность видимого поглощения $\mathrm{CO}_{2}$ комплексом «ценоз редиса - ППС» и гросс-фотосинтез растений редиса варианта Б к концу вегетационного периода достовер- но были выше аналогичных показателей в вариантах А и В (рис. 5 и 7).

Минеральный состав растений редиса. Сравнение относительного содержания макроэлементов в листьях и корнеплодах растений, выращенных в 1-м и во 2-м циклах, показывает, что существенного влияния на минеральный состав растений условия выращивания не оказали (табл. 4). Тем не менее в листьях контрольных растений цикла 2 от- 
Таблица 4. Минеральный состав растений в зависимости от способа внесения растительных отходов в корнеобитаемый субстрат ( \% в сухом веществе)

\begin{tabular}{|c|c|c|c|c|c|c|c|c|}
\hline \multicolumn{2}{|r|}{ Вариант } & Образец & K & $\mathrm{P}$ & $\mathrm{S}$ & $\mathrm{Ca}$ & $\mathrm{Mg}$ & $\mathrm{N}$ \\
\hline \multicolumn{2}{|r|}{ Цикл 1} & \multirow{5}{*}{ Листья } & $9,30^{\mathrm{a}}$ & $0,44^{\mathrm{a}}$ & $0,74^{\mathrm{a}}$ & $2,80^{\mathrm{a}}$ & $0,65^{\mathrm{a}}$ & $5,11^{\mathrm{a}}$ \\
\hline \multirow{4}{*}{ 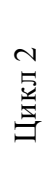 } & Контроль & & $5,63^{\mathrm{b}}$ & $0,29^{\mathrm{b}}$ & $0,78^{\mathrm{a}}$ & $2,28^{\mathrm{a}}$ & $0,57^{\mathrm{a}}$ & $4,84^{\mathrm{a}}$ \\
\hline & Вариант A & & $10,00^{\mathrm{a}}$ & $0,36^{\mathrm{a}, \mathrm{b}}$ & $0,80^{\mathrm{a}}$ & $2,36^{\mathrm{a}}$ & $0,67^{\mathrm{a}}$ & $5,18^{\mathrm{a}}$ \\
\hline & Вариант Б & & $7,81^{\mathrm{a}}$ & $0,39^{\mathrm{a}}$ & $0,77^{\mathrm{a}}$ & $2,32^{\mathrm{a}}$ & $0,59^{\mathrm{a}}$ & $4,64^{\mathrm{a}}$ \\
\hline & Вариант В & & $8,44^{\mathrm{a}}$ & $0,42^{\mathrm{a}}$ & $0,88^{\mathrm{a}}$ & $2,56^{\mathrm{a}}$ & $0,69^{\mathrm{a}}$ & $5,65^{\mathrm{a}}$ \\
\hline \multirow{5}{*}{$\begin{array}{l}N \\
5 \\
\vdots \\
\end{array}$} & Цикл 1 & \multirow{5}{*}{ Корнеплоды } & $7,42^{\mathrm{a}}$ & $0,32^{\mathrm{a}}$ & $0,37^{\mathrm{a}}$ & $0,36^{\mathrm{a}}$ & $0,24^{\mathrm{a}}$ & $2,51^{\mathrm{a}}$ \\
\hline & Контроль & & $8,25^{\mathrm{a}}$ & $0,20^{\mathrm{b}}$ & $0,39^{\mathrm{a}}$ & $0,49^{b}$ & $0,26^{\mathrm{a}}$ & $2,32^{\mathrm{a}}$ \\
\hline & Вариант A & & $8,13^{\mathrm{a}}$ & $0,22^{\mathrm{b}}$ & $0,36^{\mathrm{a}}$ & $0,41^{\mathrm{a}}$ & $0,25^{\mathrm{a}}$ & $2,41^{\mathrm{a}}$ \\
\hline & Вариант Б & & $7,91^{\mathrm{a}}$ & $0,21^{\mathrm{b}}$ & $0,45^{\mathrm{a}}$ & $0,46^{\mathrm{b}}$ & $0,21^{\mathrm{a}}$ & $2,52^{\mathrm{a}}$ \\
\hline & Вариант В & & $8,50^{\mathrm{a}}$ & $0,18^{\mathrm{b}}$ & $0,36^{\mathrm{a}}$ & $0,50^{\mathrm{b}}$ & $0,26^{\mathrm{a}}$ & $2,50^{\mathrm{a}}$ \\
\hline
\end{tabular}

Контроль - без внесения растительной биомассы в ППС; вариант А - биологический метод минерализации растительной биомассы; вариант Б - комбинированный метод минерализации растительной биомассы; вариант В - физико-химический метод минерализации растительной биомассы. Сравнение построчное в пределах образца. Различные буквы между вариантами указывают на достоверные различия, оцененные по t-критерию Стьюдента при $\alpha \leq 0,05$.

мечено достоверное снижение содержания калия и фосфора по сравнению с другими вариантами. В то же время в корнеплодах растений всех вариантов цикла 2 наблюдалось снижение содержания фосфора и увеличение содержания кальция по сравнению с их содержанием в корнеплодах растений, выращенных в 1-м цикле (табл. 4).

Урожай ценозов редиса. Более высокая интенсивность фотосинтеза ценоза редиса варианта Б привела к увеличению общего урожая растений этого варианта по сравнению с урожаем растений вариантов А и В (рис. 8). Наименьшим оказался урожай общей биомассы редиса варианта А. Использование минерализованных растительных остатков (вариант В) тоже привело не к увеличению продуктивности растений, а скоpeе, наоборот, к ее снижению. На биомассу корнеплодов внутри цикла 2 способ внесения растительных отходов значимо не повлиял, но биомасса корнеплодов варианта В оказалась достоверно ниже, чем у растений контрольного варианта и варианта Б 2-го цикла (рис. 8).

Общий урожай контрольных растений и растений варианта Б цикла 2 достоверно не отличался от урожая растений редиса, выращенных в первом цикле. Но во втором цикле масса корнеплодов всех вариантов оказалась ниже, чем урожай корнеплодов растений, выращенных в цикле 1. Возможно, это связано с изменением гормонального статуса субстрата, но решение этой проблемы требует дальнейших исследований.

При изучении роли внесения остатков соломы зерновых культур в почву в условиях орошаемого и неорошаемого земледелия было показано, что поступление растительных остатков в почву имеет большое значение, поскольку это основной источник органического углерода. Поступление органического углерода улучшает такие показатели почвенного плодородия, как структура, плотность и водоудерживающая способность почвы, а также микробиологическую активность по- 


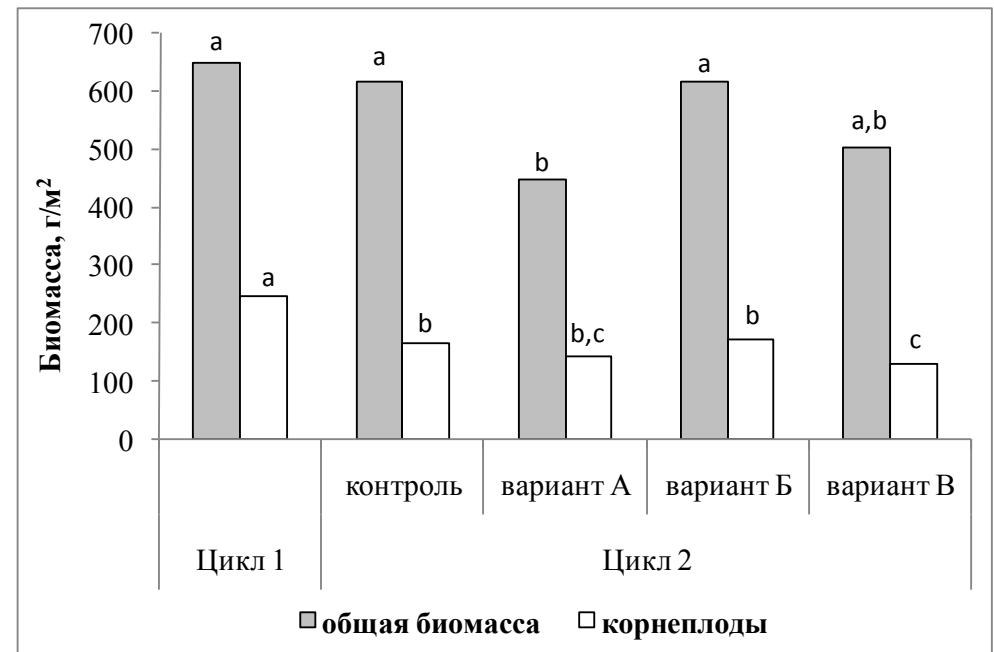

Рис. 8. Урожай ценозов редиса в расчете на сухое вещество в зависимости от способа внесения в корнеобитаемую среду растительных отходов. Различные буквы над столбцами указывают на статистически достоверные различия по t-критерию Стьюдента при $\alpha \leq 0,05$. Сравнение в пределах образца. Обозначения вариантов эксперимента как на рис. 1

чвы, что способствует повышению урожайности возделываемых культур (Khan et al., 2007; Tarkalson et al., 2009). Но эти же авторы считают, что в случае, когда растительные остатки остаются в почве, из-за временной иммобилизации азота микроорганизмами рекомендуется дополнительно вносить азотные удобрения. Видимо, именно поэтому сочетание биологического и физико-химического методов разложения растительных отходов оказалось наиболее благоприятным для выращивания редиса: внесение несъедобной биомассы редиса поддержало микробиологическую активность ППС, а минерализация соломы обеспечила растения доступными формами азота.

\section{Заключение}

Приведенные результаты исследования влияния способа внесения несъедобной растительной биомассы пшеницы и редиса в корнеобитаемую среду демонстрируют, что внесение соломы пшеницы непосредственно в субстрат приводит к снижению урожая растений. Также не имеет положительного влияния на урожай и минерализация физико-химическим способом всех растительных отходов. При этом следует отметить, что способ минерализации несъедобной биомассы пшеницы и редиса перед внесением ее в корнеобитаемый субстрат не оказал значимого влияния на относительное содержание макроэлементов и на функциональную активность фотосинтетического аппарата листьев редиса. Из исследованных методов минерализации оптимальным является комбинирование физико-химического метода минерализации соломы пшеницы перекисью водорода в переменном магнитном поле и биологического метода минерализации несъедобной биомассы редиса.

Исследование выполнено за счет гранта Российского научного фонда (проект № 14-1400599). 


\section{Список литературы}

1. Бохински P. (1987) Современные воззрения в биохимии. М.: Мир, 544 с. [Bohinski R. (1987) Modern concepts in Biochemistry. Moscow: Mir, 544 p.]

2. Ушакова С.А., Тихомиров А.А., Величко В.В., Головко Т.К., Табаленкова Г.Н., Захожий И.Г., Матусевич В.В. (2010) Сравнительная оценка продкуктивности зеленных культур, возможных представителей звена высших растений биорегенеративных систем жизнеобеспечения. Авиакосмическая и экологическая медицина 44 (3): 42-46. [Ushakova S.A., Tikhomirov A.A., Velichko V.V., Golovko T.K., Zakhozhiy I.G., Matusevich V.V. (2010) Comparative evaluation of productivity of several green cultures as potential higher plant components of bio-regenerative systems of life support. Aviakosmicheskaia i ekologicheskaia meditsina 44 (3): 42-46. (In Russian)]

3. Мануковский Н.С., Абросов Н.С., Косолапова Л.Г. (1990) Кинетика биоконверсии лигноцеллюлоз. Новосибирск: Наука, 112 с. [Manukovsky N.S., Abrosov N.S., Kosolapova L.G. (1990) Kinetics of lignocellulose bioconversion. Novosibirsk: Nauka, 112 p.]

4. Минеев В.Г. (2001) Практикум по агрохимии. М.: Изд-во Московского университета, 689 c. [Mineev V.G. (2001) Practical work on agrochemistry. Moscow: Publishing house of Moscow university, 689 p.]

5. Мишустин Е.Н. (1972) Микроорганизмы и продуктивность земледелия. М.: Наука, 343 с. [Mishustin E.N. (1972) Microorganisms and productivity of agriculture. Moscow: Nauka, 343 p.]

6. Bamsey M., Graham T., Stasiak M., Berinstain A., Scott A., Rondeau Vuk T., Dixon M. (2009) Canadian advanced life support capacities and future directions. Adv. Space Res. 44 (2): 151-161.

7. Cheng Q., Guo S., Ai W., Tang Y., Qin L. (2013) A straw-soil co-composting and evaluation for plant substrate in BLSS. Adv. Space Res. 5 (13): 483-491.

8. Gitelson J.I., Lisovsky G.M., MacElroy R.D. (2003) Manmade closed ecological systems. New York: Taylor and Francis, 402 p.

9. Gros J.-B., Lasseur C., Tikhomirov A.A., Manukovsky N.S., Ushakova S.A., Zolotukhin I.G., Gribovskaya I.V., Kovalev V.S. (2004) Soil-like substrate for plant growing derived from inedible plant mass: preparing, composition, fertility. Acta Hort. 644: 151-155.

10. Gurevich Yu.L., Manukovsky N.S., Kovalev V.S., Degermendzy A.G., Hu D., Hu E., Liu H. (2008) The carbon cycle in a bioregenerative life support system with a soil-like substrate. Acta Astronautica 63: 1043 - 1048.

11. Hu D., Zhang H., Li L., Zhou R., Sun Y. (2013) Mathematical modeling, design and optimization of conceptual configuration of soil-like substrate bioreactor based on system dynamics and digital simulation. Ecological Engineering 51: 45-58.

12. Liu H., Yu C.Y., Manukovsky N.S., Kovalev V.S., Gurevich Yu.L., Wang J. (2008) A conceptual configuration of the lunar base bioregenerative life support system including soil-like substrate for growing plants. Adv. Space Res. 42 (6): 1080-1088.

13. Kalacheva G.S., Gubanov V.G., Gribovskaya I.V., Gladchenko I.A., Zinenko G.K., Savitsky S.V. (2002) Chemical analysis of lake Shira water (1997-2000). Aquat. Ecol. 36: 123-141.

14. Khan S.A., Mulvaney R.L., Ellsworth T.R., Boast C.W. (2007). The myth of nitrogen fertilization for soil carbon sequestration. Journal of Environmental Quality 36: 1821-1832. 
15. Kudenko Yu.A., Gribovskaya I.V., Pavlenko R.A. (1997) Mineralization of wastes of human vital activity and plants to be used in a life support system. Acta Astronautica 41 (3): 193-196.

16. Kudenko Yu.A., Gribovskaya I.A., Zolotukchin I.G. (2000) Physical-chemical treatment of wastes: a way to close turnover of elements in LSS. Acta Astronautica 46: 585-589.

17. Manukovsky N.S., Kovalev V.S., Rygalov V.Ye., Zolotukhin I.G. (1997) Waste bioregeneration in life support CES: development of soil organic substrate. Adv. Space Res. 10: 1827-1832.

18. Roháček K. (2002) Chlorophyll fluorescence parameters: thedefinitions, photosynthetic meaning, and mutual relationships. Photosynthetica 40: 13-29.

19. Roháček K., Barták M. (1999) Technique of the modulated chlorophyll fluorescence: basic concepts, useful parameters, and some applications. Photosynthetica 37: 339-363.

20. Tarkalson D.D., Brown B., Kok H., and Bjorneberg D.L. (2009) Impact of removing straw from wheat and barley fields: A literature review. Better Crops 93 (3): 17 - 19.

21. Tikhomirov A.A., Ushakova S.A., Manukovsky N.S., Lisovsky G.M., Kudenko Yu.A., Kovalev V.S., Gribovskaya I.V., Tirranen L.S., Zolotukhin I.G., Gros J.B. ,Lasseur Ch. (2003) Synthesis of biomass and utilization of plants wastes in a physical model of biological life-support system. Acta Astronautica 53: 249-257.

22. Tikhomirov A.A., Ushakova S.A., Kovaleva N.P., Lamaze B., Lobo M., Lasseur Ch. (2007) Biological life support systems for a Mars mission planetary base: Problems and prospects. Adv. Space Res. 40 (11): 1741-1745.

23. Tikhomirov A.A., Ushakova S.A., Velichko V.V., Tikhomirova N.A., Kudenko Yu.A., Gribovskaya I.V., Gros J.-B., Lasseur Ch. (2011) Assessment of the possibility of establishing material cycling in an experimental model of the bio-technical life support system with plant and human wastes included in mass exchange. Acta Astronautica 68: 1548-1554.

24. van Kooten O., Snel J.F. (1990) The use of chlorophyll fluorescence nomenclature in plant stress physiology. Photosynth. Res. 25: 147-150. 